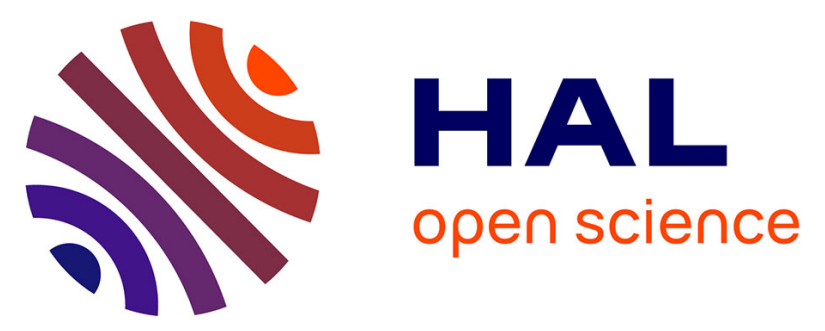

\title{
Phylogeography and demographic inference in Nacella (Patinigera) concinna (Strebel, 1908) in the western Antarctic Peninsula
}

\author{
Claudio A. González-Wevar, Bruno David, Elie Poulin
}

\section{To cite this version:}

Claudio A. González-Wevar, Bruno David, Elie Poulin. Phylogeography and demographic inference in Nacella (Patinigera) concinna (Strebel, 1908) in the western Antarctic Peninsula. Deep Sea Research Part II: Topical Studies in Oceanography, 2011, 58 (1-2), pp.220-229. 10.1016/j.dsr2.2010.05.026 . hal-00567520

\section{HAL Id: hal-00567520 \\ https://hal.science/hal-00567520}

Submitted on 30 Nov 2021

HAL is a multi-disciplinary open access archive for the deposit and dissemination of scientific research documents, whether they are published or not. The documents may come from teaching and research institutions in France or abroad, or from public or private research centers.
L'archive ouverte pluridisciplinaire HAL, est destinée au dépôt et à la diffusion de documents scientifiques de niveau recherche, publiés ou non, émanant des établissements d'enseignement et de recherche français ou étrangers, des laboratoires publics ou privés.

\section{(ㅇ)(1) $\$$}

Distributed under a Creative Commons Attribution - NonCommerciall 4.0 International 


\title{
Phylogeography and demographic inference in Nacella (Patinigera) concinna (Strebel, 1908) in the western Antarctic Peninsula
}

\author{
Claudio A. González-Wevar ${ }^{\text {a,n }}$, Bruno David ${ }^{\mathrm{b}}$, Elie Poulin ${ }^{\mathrm{a}}$ \\ a Instituto de Ecología y Biodiversidad (IEB), Departamento de Ciencias Ecológicas, Facultad de Ciencias, Universidad de Chile, Santiago, Chile \\ ${ }^{\mathrm{b}}$ Laboratoire Biogéosciences, CNRS, Centre des Sciences de la Terre, Université de Bourgogne, Dijon, France
}

\begin{abstract}
Endemic to Antarctic ecosystems, the limpet Nacella (Patinigera) concinna (Strebel, 1908) is an abundant and dominant marine benthic invertebrate of the intertidal and shallow subtidal zone. In order to examine the phylogeographic pattern and historical demography of the species along the western Antarctic Peninsula, we amplified 663 bp of the mitochondrial DNA cytochrome oxidase subunit I of $161 \mathrm{~N}$. concinna specimens from five localities, as well as two specimens from South Georgia and Sub-Antarctic Marion Island. As two different morphotypes, one characterized by an elevated shell in the intertidal and the other by a flat one in the subtidal, have been recurrently reported for this species, we also compared intertidal and subtidal samples from two localities of King George Island (Admiralty and Fildes Bay) through geometric morphometric and genetic analyses. As a result, elliptic Fourier analyses on shell shape morphology detected highly significant differences between intertidal and subtidal morphotypes. In contrast, mtDNA analyses between these morphotypes did not detect statistical differences between them and support the hypothesis that subtidal and intertidal $N$. concinna forms correspond to be the same population unit.

Genetic analyses depicted low levels of haplotypic and nucleotide diversity in N. concinna in all localities. Among populations, comparisons did not detect any genetic structure, supporting the existence of a single genetic unit along the western Antarctic Peninsula. A marked L-shaped distribution of pairwise differences and significant negative Tajima's $D$ and Fu's $F_{S}$ indices suggest the existence of a recent demographic expansion of this species. Time estimations corrected by the "time dependency of molecular rate" hypothesis for this demographic event (7,500-22,000 years ago) fit well with the last glacial-interglacial transition period. Low levels of genetic diversity in $N$. concinna could reflect the dramatic effect of glacial periods on population sizes, especially in Antarctic species with narrow bathymetric ranges.

Genetic similarities between South Georgia and Antarctic samples, as well as between Nacella delesserti (Philippi, 1849) and N. concinna (Strebel, 1908) fell within the range of intraspecific variation. The genetic proximity between sub-Antarctic $N$. delesserti and the Antarctic limpet could be explained through north-eastward long-distance dispersion events during the late Pleistocene.
\end{abstract}

\section{Introduction}

Antarctica is considered to be an island continent isolated from other regions of the Southern hemisphere by geographic distance, water currents and extreme environmental conditions such as low temperatures, the presence of ice and exceptional seasonality (Crame, 1999; Clarke et al., 2004, 2005; Strugnell and Linse, 2005). The current biodiversity in Antarctica has resulted from different biogeographic and evolutionary processes operating over this continent since the Mesozoic (Zachos et al., 2001; Brandt, 2005;

\footnotetext{
* Corresponding author.

E-mail address: cagonzalez@uach.cl (C.A. González-Wevar).
}

Brandt et al., 2007; Rogers, 2007). Marginal and extreme environments are thought to enhance the evolution of novel species through habitat fragmentation and strong selective pressure, thus driving the appearance and establishment of new taxa. In the particular case of Antarctica, this situation may have been favored by the elimination of competitors and predators, as well as by the stimulation of adaptation and speciation processes in survivors (Crame, 1999; Strugnell and Linse, 2005).

It is also interesting to note how the progressive isolation of this continent has led to a drastic extinction of plants and animals in the terrestrial realm (Clarke and Crame, 1989; Convey et al., 2008). In the Antarctic Ocean, similar changes are marked by the reduction of several key benthic groups, which are abundant and dominant in adjacent sub-Antarctic regions, such as brachyuran 
crabs, lobsters, cartilaginous and non-notothenoid fishes. Nevertheless, other groups like sponges, bryozoans, sea spiders, echinoderms, amphipods and isopods are abounding and diverse, indicating that the continent's isolation and climatic changes have not impeded their success (Crame, 1999; Arntz and Ríos, 1999; Gray, 2001; Clarke et al., 2004). Nearshore benthic assemblages in Antarctica are diverse and with high standing stocks (Clarke and Johnston, 2003; Bowden, 2005). In fact, the modern Antarctic benthic fauna includes more than 4000 species and comprise a significant part of Earth's biodiversity (Clarke et al., 2004; Gutt et al., 2004; Peck et al., 2005). Many of these species are found only in this continent and endemism may reach over $90 \%$ for some groups of Antarctic invertebrates (Clarke and Johnston, 2003). The marked changes in the diversity of invertebrate groups over the last $40 \mathrm{Myr}$ indicate that Antarctica offers good insight into macro-evolutionary processes, especially the relationship between speciation and extinction (Strugnell and Linse, 2005). At the same time, this particular region presents opportunities for studying life-history adaptations in slow growing benthic species that persist in habitats with high seasonality and frequent natural disturbance (Bowden, 2005).

Members of the genus Nacella Schumacher, 1817 (Nacellidae: Patellogastropoda) are exclusive inhabitants of the Antarctic-SubAntarctic ecosystems (Powell, 1973). Currently, the genus is composed of 15 nominal species distributed in several regions of the Southern Ocean, like the Antarctic Peninsula, the Magellan province, the Kerguelen province and the Antipodean province in Southern New Zealand (Powell, 1973; Valdovinos and Rüth, 2005). Recent phylogenetic studies indicate that the origin of Nacella relates to the Middle Miocene Climatic Transition ( $\sim 14 \mathrm{Ma})$, long after the separation of the Southern Ocean Continents, like Antarctica and South America (González-Wevar et al., 2010). Molecular analyses using two mitochondrial markers ( $\mathrm{COI}$ and $\mathrm{CytB}$ ) suggest that the diversification of the genus can be divided into two main phases: a first gradual appearance of Nacella in different biogeographic regions like Antarctica, South America and the Kerguelen Province, between 9.0-5.0 Ma; a second diversification stage characterized by a rapid morphological and ecological radiation of the genus in the Magellanic Province during the Pleistocene ( 2.0-0.4 Ma; González-Wevar et al., 2010).

In Antarctica, the true limpet $N$. concinna (Strebel, 1908) is one of the most conspicuous and dominant marine benthic macroinvertebrates (Walker, 1972; Picken, 1980; Picken and Allan, 1983; Peck and Veal, 2001). The species is distributed along the Antarctic Peninsula and its adjacent island systems, like the Palmer Archipelago, Seymour and Paulet Island, along the islands of the Scotia Arc (South Georgia Island, South Orkney Islands and South Shetland Islands) and Bouvet Island (Powell, 1973). It is a very common species in the nearshore of the West Antarctic environment with a mean population density of $124 \times 21 \mathrm{~m}^{-2}$ on Signy Island (Picken, 1980). The species inhabits a bathymetric range from the intertidal zone down to $110 \mathrm{~m}$, where it mainly grazes on microphytobenthos and microalgae (Picken, 1980; Davenport, 1988; Brêthes et al., 1994). Like many Antarctic marine organisms, $N$. concinna is also described as a long-lived organism, reaching shell lengths of $\sim 41 \mathrm{~mm}$ in 21 years, and some specimens have even lived up to more than 70 years (Picken, 1980). N. concinna is a dioecious species with external fertilization and broadcast spawners with pelagic larvae. Unusually for a patellogastropod, $N$. concinna forms spawning clusters of 3-35 individuals for up to seven days during the spring bloom period (Picken and Allan, 1983; Stanwell-Smith and Clarke, 1998).

The species was originally described as Patella polaris during the XVII century and Strebel (1908) distinguished two different forms, namely, a shallow water morph named Patinella polaris and a deeper water one called $P$. polaris var. concinna. Later, Powell (1973) recognized no differences between these forms and renamed both $N$. concinna, within the subgenus Patinigera. Walker (1972) and Picken (1980) recorded different bathymetric migration patterns between these intertidal and subtidal forms, with the first one migrating vertically on a seasonal mode as a response to decreasing temperatures and ice formation while the second one remains far below the low tide level all year. The elevated intertidal shape allows higher water volume retention offering an advantage towards avoiding desiccation, to extreme temperature ranges and hypoxia conditions. According to Nolan (1991) this form also favors colonizing the intertidal over the sublittoral form highly preferred by predators. Beaumont and Wei (1991) performed a morphological and genetic study on the species. In that study, morphological differences were corroborated and the subtidal group showed larger height/length ratios compared to the intertidal one. Morphological and genetic studies using five allozymic polymorphic loci (Es-1, Icd, Gpi, Pgm-1 and Got-1) in specimens of both sub-populations indicate that these forms are genetically identical, without evidence of any structure between them. On other hand, morphology showed significant differences in shell shape, suggesting that morphological variation in this species results from environmentally induced phenotypic plasticity (Beaumont and Wei, 1991). Recent morphometric and molecular studies using ISSR-PCR markers in three localities along the Antarctic Peninsula confirmed the morphological differences between intertidal and subtidal forms. At the same time, the molecular markers also detected significant genetic differences between these forms, indicating that they could correspond to different populations with low levels of gene flow (de Aranzamendi et al., 2008).

Despite the marked interest in the ecology, colonization, physiology, life history and evolution of Antarctic marine fauna, only a limited number of studies have examined genetic diversity patterns in these organisms. Molecular studies in euphausiids and nothotheniidae fishes have showed that these groups exhibit high levels of genetic differences in the Southern Ocean (Bargelloni et al., 2000). Nucleotide sequence data from mitochondrial genes have revealed high levels of genetic structure and cryptic speciation in the crinoid Promachocrinus kerguelenensis (Wilson et al., 2007). A recent molecular study in nudibranch Doris kerguelenensis showed high levels of genetic diversity in this species, pointing towards recent explosive radiation (Wilson et al., 2009). In a study on the Antarctic silverfish Pleuragramma antarcticum, Zane et al. (2006), we identified high levels of polymorphism. In spite of the high levels of genetic diversity, the authors detected no association between localities and a weak population structure in the species.

In order to examine the evolutionary history of $N$. concinna in the Antarctic Peninsula, we reconstructed intraspecific phylogeographic relationships along the Antarctic Peninsula and analyzed patterns of haplotype frequencies in the species. For this, we used DNA sequences from the mitochondrial cytochrome oxidase subunit I gene. Mitochondrial genetic markers, and especially COI, have been successfully used to obtain a first insight into populations' demographic histories (Zane et al., 2006; Wilson et al., 2007; Mahon et al., 2008). The distribution of $N$. concinna in Antarctica is restricted to ice-free zones; its narrow bathymetric range and reproduction mode with free-living larvae makes this species a suitable model to study the effect of Pleistocene glaciations on the demography of Antarctic species. We included subtidal and intertidal specimens from two localities, so as to determine the degree of genetic divergence among these different morphologies. In these samples, we also conducted geometric morphometric analyses to determine the presence of morphological differences between these groups. 


\section{Material and methods}

\subsection{Sampling, DNA extraction, PCR amplifications and alignment}

Nacella concinna specimens from five different localities along the Antarctic Peninsula were collected by scuba diving during the years 2002-2008, namely, Elephant Island, Admiralty and Fildes Bays in King George Island, and Covadonga and South Bays along the west Antarctic Peninsula (Table 1). We obtained subtidal and intertidal specimens from two localities: Admiralty Bay ( $\mathrm{AB}$ ) and Fildes Bay (FB). We also included one specimen from South Georgia Island and one specimen of $N$. delesserti (Philippi, 1849) from sub-Antarctic Marion Island in the analyses (Fig. 1A and B). Animals were fixed in 95\% ethanol and DNA was extracted from the mantle tissue, using the salting-out method described by Aljanabi and Martinez (1997). A partial fragment $(663 \mathrm{bp}$ ) of the mtDNA gene cytochrome oxidase subunit i (COI) was amplified using specific primers: COI-NacF (5'-CTG GGC TTG CTG GGA CTG GTT-3') and COI-NacR (5'-AAT AAA TGC TGA TAA AGA ATA-3'; González-Wevar et al., 2010). Amplifications were done in a $25 \mu \mathrm{l}$ reaction volume consisting of $17.5 \mu \mathrm{l}$ of double-distilled water, $200 \mathrm{mM}$ dNTPs, $0.5 \mu \mathrm{l}$ of each primer, $1 \mathrm{U}$ Taq (Promega), $2.5 \mu \mathrm{l} 10 \times$ buffer $(50 \mathrm{mM} \mathrm{KCl}, 10 \mathrm{mM}$ Tris- $\mathrm{HCl}, \mathrm{pH} 8.0$ ), $1.0 \mu \mathrm{l}$ of $50 \mathrm{mM} \mathrm{MgCl}_{2}$ and $50 \mathrm{ng}$ of DNA. Thermal cycling parameters included an initial denaturation step at $94{ }^{\circ} \mathrm{C}$ for $3 \mathrm{~min}$, followed by 40 cycles at $94{ }^{\circ} \mathrm{C}$ for $1 \mathrm{~min}, 48{ }^{\circ} \mathrm{C}$ for $45 \mathrm{~s}$ and $72{ }^{\circ} \mathrm{C}$ for $1 \mathrm{~min}$, which ended with a final 6 min extension at $72{ }^{\circ} \mathrm{C}$. Double stranded PCR products were purified using QIAquick Gel Extraction Kit (QIAGEN). Purified products were sequenced in both directions using an Automatic Sequencer $3730 \times 1$ (Macrogen). All $N$. concinna haplotypes sequences will be deposited in GenBank.
Sequences were edited using Proseq 2.91 (Filatov, 2002) and aligned with ClustalW (Thompson et al., 1992). After sequence editing, COI data were translated into amino acids to check for premature stop codons, which are evidence of sequencing errors or the presence of nuclear pseudogenes. We performed a DNA saturation analysis following Roe and Sperling (2007) to examine how levels of saturation changes across the COI.

\subsection{Population genetic structure}

Levels of genetic polymorphism in $N$. concinna were determined by standard diversity indices, such as the number of haplotypes $(k)$, segregating sites $(S)$ and haplotype diversity $(H)$, for each locality from the COI aligned sequences with DnaSP 5.00.07 (Librado and Rozas, 2009). We also estimated average pairwise sequence differences $(\Pi)$ and nucleotide diversity $(\pi)$, according to Nei (1987).

Levels of genetic differentiation between localities of $N$. concinna were estimated by pairwise $\Phi_{\mathrm{ST}}$ using Arlequin v.3.11 (Excoffier et al., 2005). This method simply counts the number of different alleles between two haplotypes using the following formulae: $\delta_{x y}=\Sigma \delta_{x y}(i)$, where $\delta_{x y}$ is the Kronecker function, equal to 1 if the alleles of the $i$-th locus are identical for both haplotypes, and equal to 0 otherwise (Excoffier et al., 2005). This parameter is analagous to $F_{\mathrm{ST}}$ and is the correlation between alleles within individuals relative to the combined population (Holsinger and Weir, 2009).

First, we performed the comparisons between the intertidal and subtidal forms from both Admiralty Bay (AB) and Fildes Bay (FB). The resulting comparisons are useful to determine whether these

Table 1

Genetic diversity indices and neutrality test in $N$. concinna.

\begin{tabular}{|c|c|c|c|c|c|c|c|c|}
\hline Locality & $N$ & $\boldsymbol{k}$ & $\boldsymbol{H}$ & $\boldsymbol{S}$ & $\Pi$ & $\pi$ & Tajima's D & Fu's $F_{S}$ \\
\hline South Bay & 31 & 5 & 0.688 & 5 & 0.888 & 0.00149 & -0.576 & -0.64 \\
\hline Elephant Island & 29 & 8 & 0.729 & 7 & 0.985 & 0.00148 & -1.34 & $-4.14^{*}$ \\
\hline Admiralty Bay & 33 & 7 & 0.471 & 6 & 0.981 & 0.00089 & -1.68 & $-4.68^{* * *}$ \\
\hline Fildes Bay & 38 & 6 & 0.565 & 6 & 0.587 & 0.00104 & -1.38 & -2.48 \\
\hline Covadonga Bay & 29 & 9 & 0.741 & 7 & 0.704 & 0.00163 & -1.17 & $-5.08^{* *}$ \\
\hline COI Total & 160 & 16 & 0.630 & 18 & 1.079 & 0.00128 & $-1.77^{*}$ & $-12.38^{* * * * *}$ \\
\hline
\end{tabular}

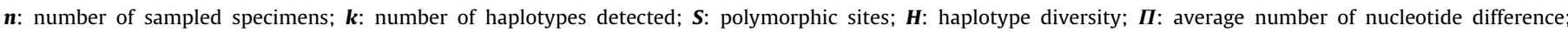
$\pi$ : nucleotide diversity.

$$
\begin{aligned}
& { }^{*} p<0.05 \\
& { }^{* *} p<0.01 \\
& * * * * * \\
& * 2<0.001 .
\end{aligned}
$$

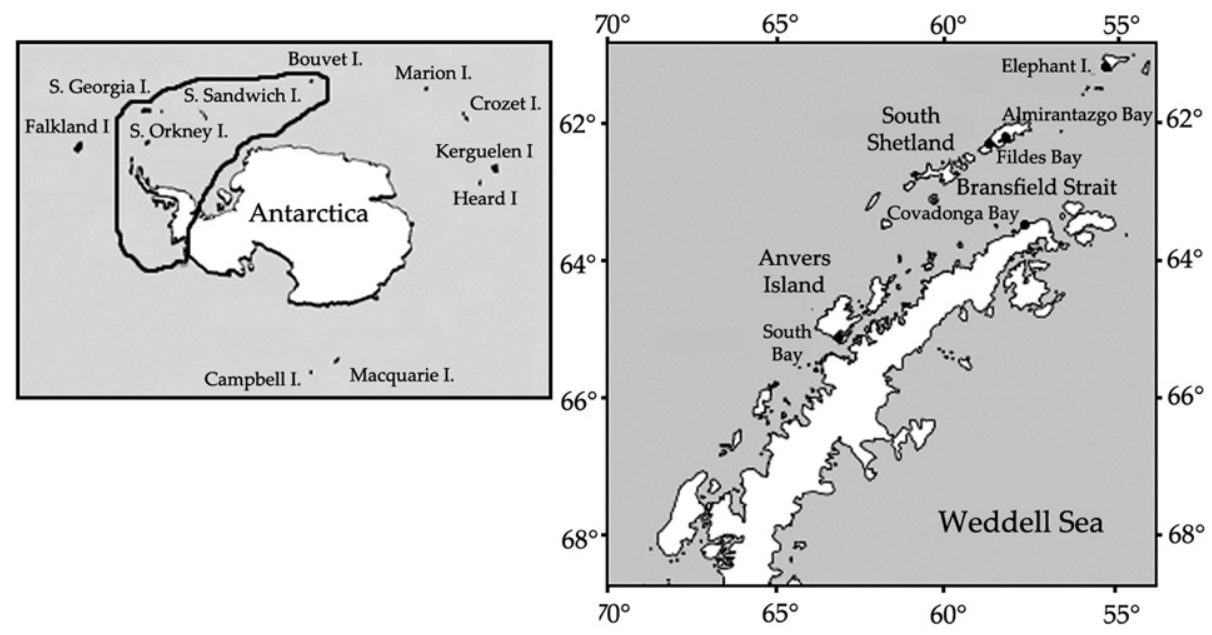

Fig. 1. (A) N. concinna distribution range in the Southern Ocean. (B) Sampling localities of $N$. concinna in the western Antarctic Peninsula. 
morphologies correspond to identical genetic units or if they should be considered in further analyses as separate sub-samples. Second, we performed pairwise $\Phi_{\mathrm{ST}}$ comparisons among all sampled localities. In parallel to this analysis we determined the average number of nucleotide differences between localities using DnaSP.

We used the program SAMOVA v.1 (SAMOVA, Spatial Analysis of Molecular Variance, Dupanloup et al., 2002) to define the number and composition of geographically homogeneous, maximally differentiated groups of populations. This method is based on a simulated annealing procedure that aims to maximize the proportion of total genetic variance due to differences among groups of populations and minimizing the variance portion among populations within groups. Differentiation indices $\Phi_{\mathrm{ST}}$ (among populations), $\Phi_{\mathrm{SC}}$ (among populations within groups) and $\Phi_{\mathrm{CT}}$ (among groups) were tested through haplotype permutation (Excoffier et al., 2005).

\subsection{Population historical inference}

Genealogical relationships among $N$. concinna localities were determined using haplotype networks constructed with the median-joining algorithm in Network v.4.5.1.0 (Röhl, 2002). This method allows simple reconstruction of phylogenies, based on intraspecific molecular data like mitochondrial DNA variation, which often are complicated to analyze, especially when dealing with large sample sizes and with small genetic divergence among individuals (Bandelt et al., 1999; Posada and Crandall, 2001). To determine past demographic changes in $N$. concinna, Tajima's $D$ and Fu's $F_{S}$ tests were calculated using DnaSP to evaluate the assumption of selective neutrality of mtDNA sequences and population mutation-drift equilibrium. Significant negative values for these tests are evidence of excess of rare polymorphisms in a population, indicating either recent demographic expansion or positive selection. We constructed a mismatch distribution of the COI sequence data to compare it to the Poisson expectation for constant and varying population sizes (Slatkin and Hudson, 1991). The rapid population growth model proposed by Rogers and Harpending (1992) rests on the estimation of three parameters: $\tau$ the date of growth/decline measured in units of mutational time $(\tau=2 \mu t$ where $t=$ time in years and $\mu=$ mutation rate per sequence per year); initial theta $\theta_{\mathrm{i}}=2 N_{\mathrm{i}} u$ (before the population growth/decline); and final theta $\theta_{\mathrm{f}}=2 N_{\mathrm{f}} u$ (after population growth/decline). The demographic expansion parameters were estimated using the nonlinear least square approach, described by Schneider and Excoffier (1999) implemented in Arlequin. Finally, by using Fluctuate v.1.44 (Kuhner et al., 1998) we coestimated the $\theta$ parameter and population growth rate $g$ from $N$. concinna COI sequences through Metropolis-Hastings sampling. This method takes a set of aligned DNA sequences as input and uses them to make maximum likelihood estimates of $\theta$ and $g$. Theta is defined as 4 times the effective population size of the mutational rate in a diploid organism, or 2 times the effective population size of the mutational rate on a haploid at present time. Parameter $g$ corresponds to the exponential growth or decline rate of the population. Positive values for this parameter indicate growth while negative ones imply decline (Kuhner et al., 1998).

\subsection{Geometric morphometrics analyses}

Shell shape variation between subtidal and intertidal $N$. concinna specimens from $\mathrm{AB}$ and $\mathrm{FB}$ was measured using outline analyses based on the elliptic Fourier analysis (EFA). Outlines were drawn from digital photographs and corresponded to a two dimensional projection of the lateral shape of the shells. We included adult specimens $(>4 \mathrm{~cm})$ in all morphometric analyses. Elliptic Fourier transformations were done using the SHAPE software (Iwata and Ukai, 2002). Elliptic Fourier descriptors (EFDs) can be used to delineate any kind of form and have been effectively applied to the evaluation of various biological shapes in plants and animals (Iwata and Ukai, 2002). This method is based on the separate Fourier decompositions of the incremental changes of the $x$ - and $y$-coordinates, as a function of the cumulative length along the outline (Renaud and Michaux, 2003, 2007). The ChainCoder module extracted the contours of the objects from digital images and stores the relevant information as chain codes. Then, the module Chc2Nef provided the normalized EFD from the chain-coded contour, and coefficients of EFD were calculated by discrete Fourier transformation following Kuhl and Giardina (1982). These coefficients were subsequently normalized to be invariant with respect to size, rotation and starting point, with a procedure based on the ellipse of the first harmonic. With the PrinComp module, we performed the principal components analyses on the variance-covariance matrix of the EFDs coefficients. Principal components' analysis is effective for summarizing the information regarding the variation contained in these coefficients (Rohlf and Archie, 1984), which were estimated using PAST v.1.77 (Hammer et al., 2001). Finally, multivariate analyses of variance (MANOVA) were performed with PAST in order to evaluate the importance of between-group differentiation relative to within-group variation. A test for significance of morphology differences (Wilk's lambda test) is also provided and Hotteling pairwise comparisons, Bonferroni corrected and uncorrected, were also performed using PAST to determine differences between morphologies and localities.

\section{Results}

\subsection{Molecular genetics}

The $N$. concinna COI sequence data set comprised 161 specimens and consisted of 663 nucleotide positions. A single specimen of $N$. delesserti from Marion Island was added to the data set for comparisons. No indels or stop codons were detected, as expected for coding regions, and they also were not saturated in the third codon position. Only one amino acid substitution was detected, out of a possibility of 220 , in the entire COI data set (translated using the invertebrate mitochondrial table; Kumar et al., 2004). A third position transversion (T-G) generated an amino acid change from isoleucine to methonine (both amino acids are type D with hydrophobic side chain). The Antarctic limpet exhibited low levels of genetic diversity along the Antarctic Peninsula; only 15 characters $(2.2 \%)$ were variable and 8 of them (1.2\%) were parsimoniously informative. Sequences were adenine and thymine (A-T) rich (61.6\%), compared to mean guanine and cytocine (G-C) content (39.4\%). Genetic diversity indices, like the number of polymorphic sites, haplotype diversity and nucleotide diversity (Table 1), were low but comparable to other molecular studies in Antarctic marine invertebrates (Díaz, 2008; Hunter and Halanych, 2008; Mahon et al., 2008; Thornhill et al., 2008; Díaz et al., 2011).

Pairwise $\Phi_{\mathrm{ST}}$ comparisons between intertidal and subtidal $N$. concinna from the Admiralty and Fildes Bays (Table 2) showed no significant difference. From this point, for both Fildes and Admiralty, we considered intertidal and subtidal samples as similar and pooled these samples for further genetic analyses.

The new pairwise $\Phi_{\mathrm{ST}}$ calculated among all five localities along South Shetland and the western Antarctic Peninsula showed no significant difference, except for the comparison between Elephant Island and Admiralty Bay $(P=0.049)$. In general, Admiralty Bay exhibited higher values for $\Phi_{\mathrm{ST}}$. General $\Phi_{\mathrm{ST}}$ 
comparisons evidenced an absence of genetic structure among $N$. concinna along $800 \mathrm{~km}$ in the South Shetland region and Western Antarctic Peninsula.

The average number of nucleotide differences between populations was very low and ranged between 0.647 and 1.039 . The highest value was recorded between the southernmost locality South Bay and Covadonga Bay in Continental Antarctic Peninsula. The average differences between the most distant localities (South Bay/Elephant Island) was 0.973, while the lowest value $(0.581)$ was recorded between intertidal and subtidal subsamples from Admiralty Bay (Tables 2 and 3). SAMOVA analysis corroborated $\Phi_{\text {ST }}$ pairwise estimations and did not recover spatial structure in $N$. concinna. However, the first partition separated Admiralty Bay from the rest of the localities, even though variances $\left(\Phi_{\mathrm{CT}}\right)$ among groups explained a small amount of the variance $(0.90 \%)$, while differences $\left(\Phi_{\mathrm{ST}}\right)$ within the populations explained $99.11 \%$ of such.

The median-joining network resulted in a typical star-like haplotype network and a very short genealogy (Fig. 2). Network analysis recovered 18 different haplotypes, including the single

Table 2

Pairwise $\Phi_{\mathrm{ST}}$ values (below diagonal) and average number of nucleotide differences (above diagonal) in N. concinna along western Antarctic Peninsula.

\begin{tabular}{lllll}
\hline & ABs & ABi & FBi & FBs \\
\hline Admiralty Bay subtidal (ABs) & - & 0.581 & 0.645 & 0.563 \\
Admiralty Bay intertidal (ABi) & -0.04175 & - & 0.749 & 0.632 \\
Fildes Bay intertidal (FBi) & -0.02655 & -0.02453 & - & 0.703 \\
Fildes Bay subtidal (FBs) & 0.02636 & -0.00607 & -0.00189 & - \\
\hline
\end{tabular}

1023 permutations, no significant values $(P<0.05)$ were detected.

Table 3

Pairwise $\Phi_{\mathrm{ST}}$ values (below diagonal) and average number of nucleotide differences between localities (above diagonal) in $N$. concinna.

\begin{tabular}{llllll}
\hline & SB & EI & AB & FB & CB \\
\hline South Bay (SB) & - & 0.973 & 0.795 & 0.837 & 1.039 \\
Elephant island (EI) & -0.0208 & - & 0.796 & 0.827 & 1.026 \\
Admiralty Bay (AB) & 0.0296 & $\mathbf{0 . 0 3 8 9}$ & - & 0.647 & 0.843 \\
Fildes Bay (FB) & 0.0030 & 0.0027 & 0.0236 & - & 0.879 \\
Covadonga Bay (CB) & -0.0166 & -0.0186 & 0.0355 & 0.0014 & - \\
\hline
\end{tabular}

1023 permutations, significant values $(P<0.05)$ are in bold.

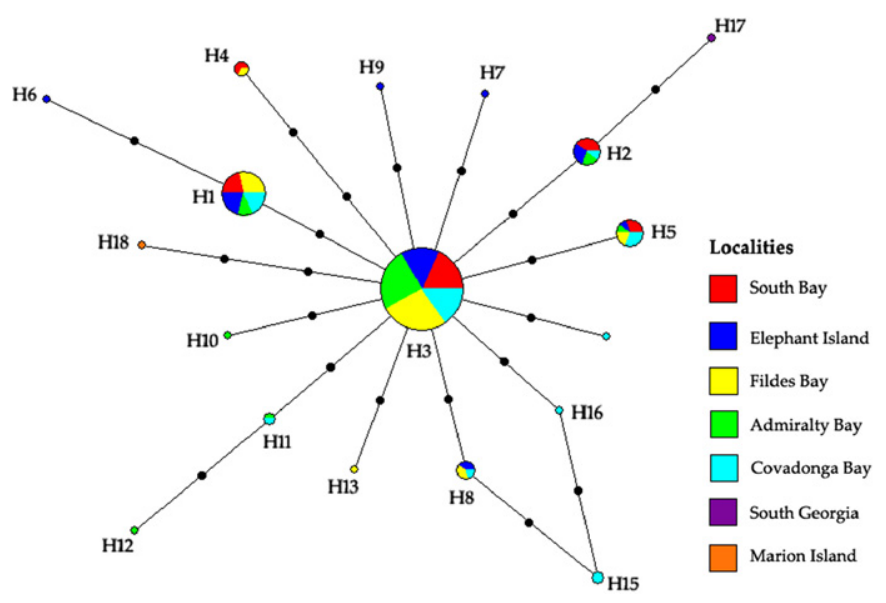

Fig. 2. Haplotype network of $162 N$. concinna and one $N$. delesserti mtDNA sequences. Each haplotype is represented by a colored circle whose size is proportional to it frequency in the whole sampling effort. - correspond to a specific mutation. specimens from South Georgia ( $N$. concinna) and Marion Island ( $N$. delesserti). The central haplotype $(\mathrm{H} 3)$ is the most frequent (58\%) and most broadly distributed one, occurring at all localities along the Antarctic Peninsula. As proposed by Posada and Crandall (2001), H3 should correspond to the most ancestral haplotype, whereas the most derived ones are linked to it with a maximum branch length of two mutational steps. Three haplotyes (H1, H2 and H5), each located at one mutational step away from $\mathrm{H} 3$, were present in most of the localities and exhibited intermediate frequency (6.2-17.4\%). The remaining 12 haplotypes occurred at low frequency, with no more than five representatives of each detected in the data set. The single haplotype from South Georgia stood two mutational steps away from $\mathrm{H} 3$ and only one step from $\mathrm{H} 2$ present in Covadonga, Fildes, Admiralty Bays and Elephant Island. In the case of $N$. delesserti, the unique haplotype from sub-Antarctic Marion Island (H18) was separated by only two mutational steps from the dominant $\mathrm{H} 3$ haplotype in N. concinna (H3; Fig. 2).

As expected from a star-like network, Tajima's $D$ and Fu's $F_{\mathrm{S}}$ neutrality tests were both significantly negative for the whole data set, indicating that this species may have experienced a recent demographic expansion event under a neutral model.

Distribution of pairwise differences among sequences was L-shaped (Fig. 4) due to the fact that the majority of the individuals shared the same haplotype (H3). The mismatch distribution did not differ significantly from the expected stepwise expansion model $\left(P_{\mathrm{SSD}}=0.31\right)$. Considering the divergence rate estimated for Cellana (1.0\% per million year, González-Wevar et al., unpublished data), the start of the expansion was estimated to be around 75,000 and 220,000 years before the present, for sudden and continuous exponential growth models, respectively (Fig. 5).

\subsection{Morphometrics}

Principal components and multivariate analyses of the morphology of the shells detected significant differences between subtidal and intertidal $N$. concinna morphotypes in both localities $\mathrm{AB}$ and FB. Principal component analyses indicated that PC1 and PC2 together explained the $91.6 \%$ of the variance (Fig. 3). PC1 explained $85.6 \%$ of the variance and mainly consisted of height shell change, while PC2 (6.4\%) corresponded to small changes in shell length (Fig. 3). Most of the variance (72\%) in shell shape morphology was explained by bathymetric variation in $N$. concinna (subtidal and intertidal forms). Differences between the localities ( $\mathrm{AB}$ and $\mathrm{FB}$ ) explained only a $12 \%$ of the variance in the data set. Hotteling pairwise comparisons detected significant levels of differentiation between subtidal and intertidal shells in both localities (same Wilks lambda $=3.96 \times 10^{-26}$; Table 4). In general, pairwise comparison results indicated that the levels of subtidal-intertidal differences were higher in several orders of magnitude than the subtidal-subtidal and intertidal-intertidal ones (Table 4).

\section{Discussion}

4.1. Absence of genetic differentiation between intertidal and subtidal forms of N. concinna, in spite of significant morphological differences

Geometric morphometric analyses are sensitive to morphological variations and, according to some authors, this approach has proved to be sensitive enough to detect a similar pattern of population structure as molecular markers (D'Anatro and Lessa, 2006). Geometric morphometric analyses in N. concinna detected 


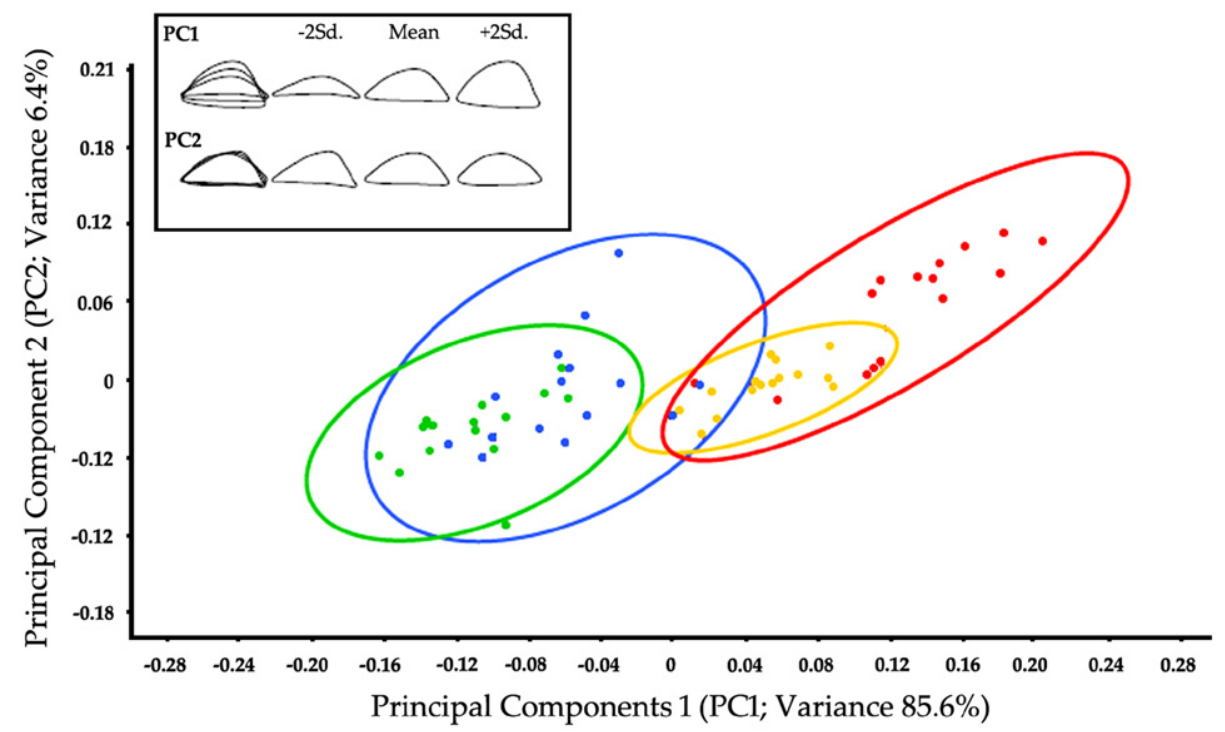

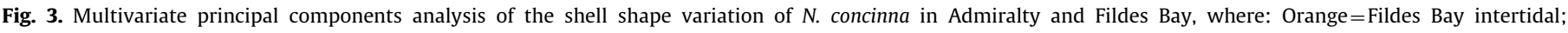

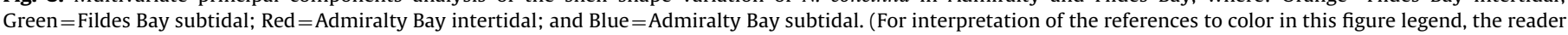
is referred to the web version of this article.).

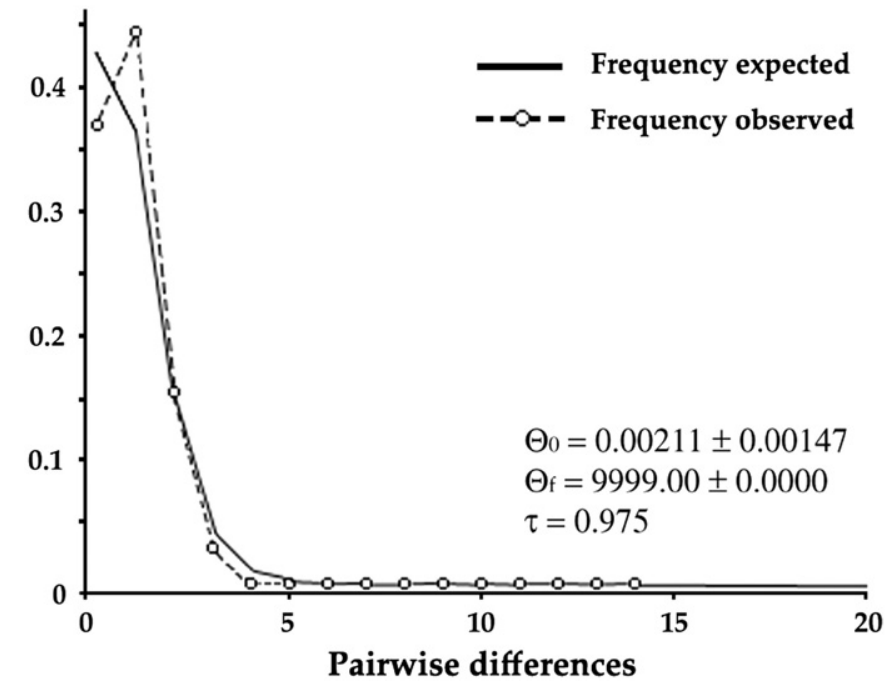

Fig. 4. Pairwise difference distribution for the cytochrome oxidase subunit I (COI) in $N$. concinna along the western Antarctic Peninsula.

significant differences between subtidal and intertidal morphologies from both Admiralty and Fildes Bays and are in total agreement with previous studies (Picken, 1980; Beaumont and Wei, 1991; Nolan, 1991; Brêthes et al., 1994; de Aranzamendi et al., 2008; Hoffman et al., 2010). At the same time, morphometric differences were also detected between $A B / F B$ subtidal and between $\mathrm{AB} / \mathrm{FB}$ intertidal morphotypes. Marked morphological differences between intertidal and subtidal specimens of $N$. concinna were also recorded in a recent study in the species in Adelaide Island, Antarctic Peninsula (Hoffman et al., 2010). These authors concluded that their morphological analyses revealed not only marked differences between these two morphotypes but also a continuous cline in shell shape from the intertidal zone down to $25 \mathrm{~m}$ depth, suggesting that the distinction between morphotypes may be artificial.

Mitochondrial DNA genetic analyses between these morphotypes from $\mathrm{AB}$ and $\mathrm{FB}$ specimens of $N$. concinna did not detect
(A)

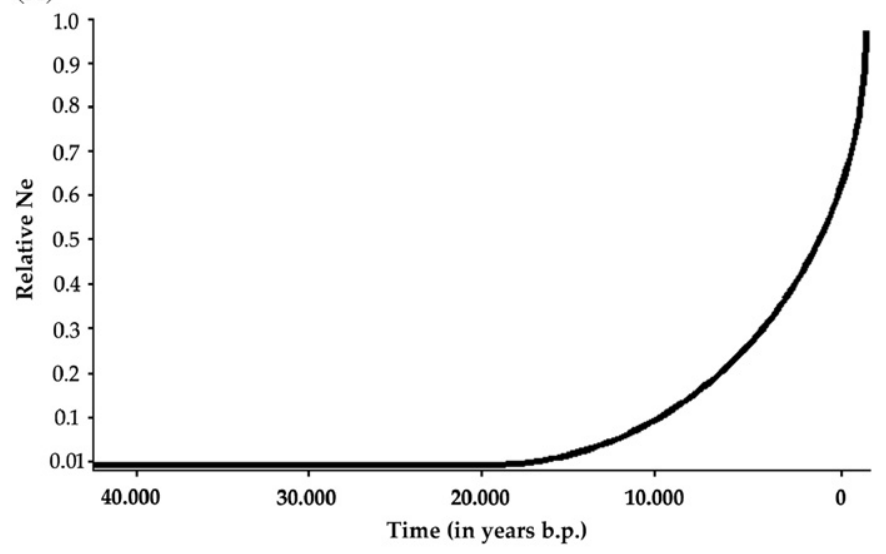

(B)

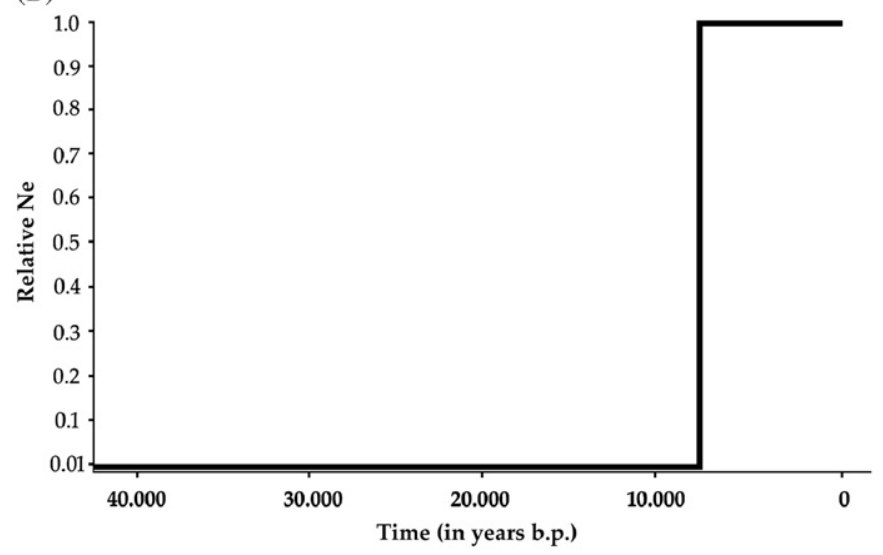

Fig. 5. Demographic expansion time estimations in $N$. concinna based on instantaneous (A) and exponential (B) growth models. Estimations incorporate "time dependency of molecular rate" correction.

statistical differences between these different morphological units. Our molecular results support the hypothesis that both subtidal and intertidal forms belong to a single $N$. concinna 


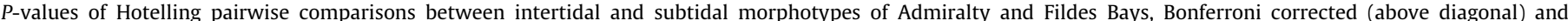
uncorrected (below diagonal).

\begin{tabular}{|c|c|c|c|c|}
\hline & $\mathrm{ABi}$ & $\mathrm{ABs}$ & $\mathrm{FBi}$ & FBs \\
\hline Admiralty Bay intertidal (ABs) & - & $3.99 \times 10^{-12}$ & $4.73 \times 10^{-5}$ & $2.41 \times 10^{-15}$ \\
\hline Almirantazgo Bay subtidal (ABi) & $2.40 \times 10^{-11}$ & - & $5.54 \times 10^{-10}$ & 0.00252 \\
\hline Fildes Bay intertidal (FBi) & 0.000284 & $3.32 \times 10^{-9}$ & - & $2.78 \times 10^{-14}$ \\
\hline Fildes Bay subtisdal (FBs) & $1.45 \times 10^{-14}$ & 0.01512 & $1.66 \times 10^{-13}$ & - \\
\hline
\end{tabular}

population unit. These results agree with Beaumont and Wei (1991), who concluded that these different morphotypes are genetically homogeneous and only represent environmentally induced phenotypic plasticity in the species. In general, shell shape, thickness and even coloration of patellogastropods is strongly affected by microhabitats and diet (Lindberg, 1998; Nakano and Ozawa, 2005,2007; Nakano and Spencer, 2007; Lindberg, 2008; de Aranzamendi et al., 2009). Phenotypic plasticity has been commonly described in several genera of the order such as Patella Linnaeus, 1758 (Côrte-Real et al., 1992; Pagarete et al., 2005), Helcion Montfort, 1810 and Nacella (Morriconi and Calvo, 1993; de Aranzamendi et al., 2008, 2009).

Taking into account the distribution of $N$. concinna in different bathymetric levels of the coast, it is possible that non-assortative mating between the morphotypes could be operating in this species. Nevertheless, the particular mode of reproduction of $N$. concinna through external fertilization, forming stacks of several individuals during the reproductive period, and its indirect development with free-living larvae (Picken, 1980) suggests that non-random mating is unlikely to occur in this species. In fact, reproductive studies indicate that intertidal morphotype migration to lower depths occur before fertilization and spawning, indicating the mixture of both morphologies at the same level of reproduction (Picken and Allan, 1983; Brêthes et al., 1994). How the segregation of this morphotypes is maintained in Antarctica is still unclear and further reproductive mating choice experiments are needed. Moreover, low differences between intertidal and subtidal forms have been recently detected by de Aranzamendi et al. (2008) working with fast evolving markers (ISSR). The existence of such genetic differences suggests that $N$. concinna would not correspond to a panmictic population along a bethymetric gradient. However, recent studies using AFLP in the species found no evidence for differentiation either between the two bathymetric morphotypes or by depths. Furthermore, a Bayesian cluster analysis did not detect any evidence for cryptic genetic structure (Hoffman et al., 2010). These findings, along with the sequence homogeneity of mitochondrial markers, support the idea that the Antarctic limpet would be just phenotypically plastic, although further studies are needed to estimate unequivocally if some degree of genetic difference do exist, besides the observed morphological variability. In any case, such differences would not challenge the existence of a single Nacella species in the shallow Antarctic realm.

\subsection{Genetic homogeneity in N. concinna along the western Antarctic Peninsula}

An interesting result of the present study is the extremely low level of genetic diversity of mtDNA COI in $N$. concinna. The Antarctic limpet represents a single genetic unit with very low levels of haplotypic and nucleotide diversity (Table 1) along the western coast of the Antarctic Peninsula. Only 16 haplotypes were found in 162 Antarctic limpets across $\sim 800 \mathrm{~km}$ (Fig. 2). Levels of genetic diversity observed in $N$. concinna are low compared to the ones observed in Nacella species from the Magellan Province (de Aranzamendi et al., 2009; González-Wevar et al., 2010). For 139 individuals of $N$. magellanica, belonging to seven localities along the Magellan Strait, we found 49 haplotypes (unpublished data). The most common haplotype in the species (H3) was shared by more than $58 \%$ of the individuals and distributed in all the analyzed localities along the Antarctic Peninsula and South Shetland Islands. Mitochondrial sequence diversity in N. concinna failed to recognize any statistically significant genetic structure in the species among the five localities examined in the Antarctic Peninsula. The only locality exhibiting a small degree of differentiation is Admiralty Bay with pairwise $\Phi_{\mathrm{ST}}$ values one order of magnitude higher than what was observed by comparing between other localities (Table 3). Admiralty Bay is a well-sheltered bay with a maximum depth of $600 \mathrm{~m}$ and a surface of about $120 \mathrm{~km}^{2}$ (Jazdzweski et al., 1986). In fact, Arnaud et al. (1998) concluded that communities of the South Shetlands appear to have distinctive features, as compared to those of continental Antarctica. The difference in pairwise comparisons between this locality and the rest of the studied sites may be a result of local oceanographic characteristics, or due to the comparatively sheltered situation of Admiralty Bay as a whole.

In theory, large population sizes should maintain high levels of genetic variability because genetic drift is low and the rate of mutation accumulation is high. Molecular diversity indices estimated in the Antarctic limpet $\left(\theta_{k}=4.9 ; \theta_{S}=1.34 ; \theta_{H}=3.15\right.$; $\theta_{\pi}=0.88$ ) would be generated by small effective sizes $(\mathrm{Ne})$ between 66.500 and 376.500 individuals. This is by far smaller than the expected population sizes found for this species, considering the high densities reported in several studies (Hedgpeth, 1969; Picken, 1980; Brêthes et al., 1994). In addition to low haplotype diversity, $N$. concinna exhibits a "star-like" genealogy, characterized by very short branches (Fig. 2), and a marked L-shaped distribution of pairwise differences (Fig. 4). Overall significant negative Tajima's $D$ and Fu's $F_{\mathrm{S}}$ indices are also evidences of excess low frequency haplotypes relative to neutral mutation-drift equilibrium. All of these results strongly support the existence of a recent demographic expansion of this species. Under this scenario, our time estimations for this historical process range between 75,000 and 220,000 years ago. These time ranges do not fit with our hypothesis that $N$. concinna was able to (re-)expand during the last glacial-interglacial transition, after the last glacial maximum (LGM; $\sim 20,000$ years). However, a time dependency of molecular evolution rates has been recently described (Ho et al., 2005). As suggested by these authors, molecular studies at population levels have estimated much higher mutation rates than the substitution rates inferred from phylogenetic (species-level) analyses. In three cases (mtDNA of avian and primate taxa) they showed that short term (1-2 Myr) mutation rates could be ten folds higher than long-term substitution rates (Ho et al., 2005, 2007). Here, we used a substitution rate estimated specifically for the limpet genus Cellana (data not published), and our estimations may be biased due to the time dependency of molecular evolution rates. Under this perspective and incorporating a simple ten-fold correction, 
our time estimations (7,500-22,000 years ago) would fit to the last glacial-interglacial transition period.

Low levels of genetic diversity detected in $N$. concinna could reflect a dramatic effect of glacial periods on population size and even on the persistence of the species along the Antarctic Peninsula. If we consider that $N$. concinna has a narrow bathymetric range $(0-110 \mathrm{~m})$, the extension of an ice sheet over the main part of the Antarctic continental shelf during glacial periods should have drastically reduced its habitat to isolated refugia in ice-free areas (Poulin et al., 2002; Thatje et al., 2005). Another possibility could be that $N$. concinna migrated northward during glaciations and returned to a southern distribution during interglacial periods. This is suggested by genetic closeness among Nacella samples from the Antarctic Peninsula, South Georgia and Marion Island. In this case, bottleneck and further founder effects may be plausible explanations for low diversity and genetic homogeneity detected in the Antarctic limpet. Our results contrasts with other studies on Antarctic marine benthic invertebrates that shows high levels of genetic diversity (Mahon et al., 2008; Thornhill et al., 2008; Krabbe et al., 2009; Wilson et al., 2009). However, most of these species exhibit a large bathymetric range that could prevent such drastic demographic impact during the recurrent Pleistocene glacial and interglacial cycles (Brey et al., 1996). Within this scenario, we could expect that the degree of genetic diversity in Antarctic benthic invertebrates would be positively related to their bathymetric range.

\subsection{Genetic cohesiveness between sub-Antarctic N. delesserti and Antarctic N. concinna}

The low levels of genetic differences between $N$. delesserti and $N$. concinna do not agree with other phylogenetic studies in the genus. Genetic similarities detected between these different taxonomic units are very low and within the range of intraspecific variation of other nacellid species (Goldstien et al., 2006; Bird et al., 2007). Recently, González-Wevar et al. (2010) have analyzed different Nacella species from Antarctica, South America and Kerguelen Province and have recovered deep molecular divergences among sub-Antarctic and Antarctic species without evidence of recent long-distance gene flow events. For example, Antarctic $N$. concinna and the Magellanic species of the genus exhibited much higher levels of genetic divergence $(8.5 \%)$ than that observed between the former and Marion Island's $N$. delesserti (0.32\%). At the same time, the species $N$. macquariensis and $N$. kerguelenensis collected from the Sub-Antarctic Heard Island (Kerguelen Province) also showed similar levels of genetic divergence (7.70\%) between them (González-Wevar et al., 2010). As mentioned above, $N$. delesserti is a sub-Antarctic endemic species from Marion Island. Interestingly, the origin of this island, located $\sim 5500 \mathrm{~km}$ away from the Antarctic Peninsula, is very recent (450,000 years; Chown et al., 2008). Therefore, the genetic proximity between $N$. delesserti and $N$. concinna could be explained through north-eastward long-distance dispersal events during the late Pleistocene, through the Circumpolar Antarctic Current. According to Beaumont and Wei (1991), N. concinna could be transported by drifting masses of algae, which supports the hypothesis that poses long-distance dispersion between Antarctica and Marion Island hypothesis. Phenotypic plasticity, as described in this and other studies, on N. concinna and other Nacella species from the Magellan Strait (Powell, 1973; Morriconi and Calvo, 1993; Valdovinos and Rüth, 2005; de Aranzamendi et al., 2008, 2009; Hoffman et al., 2010; González-Wevar et al., 2010) could have enhanced morphological differentiation of $N$. delesserti in Marion Island, and this could explain the described differences between this species and the Antarctic limpet (Powell, 1973). Because of the late Pleistocene origin of Marion Island, COI sequences as well as other mitochondrial and nuclear DNA genes (data not published) could not provide adequate resolutions to distinguish whether these two morphotypes correspond to different species. More individuals and localities of Marion Island's $N$. delesserti and faster evolving molecular markers are needed in order to offer a better explanation of this last finding.

\section{Acknowledgments}

We are grateful to the following people and museums for the help in field work, data analyses and for contributing specimens to this study: Tomoyuki Nakano, Hamish Spencer, César Cárdenas, Christian Ibañez, Ceridwen Fraser; Museo Nacional de Historia Natural Chile, Santiago, Chile, Australian Museum, Sydney, and National Museum of Nature and Science, Tokyo.

This study was supported by the Grants INACH B_01_07, Conicyt Ph.D. and thesis grants nos D-21060218, 24090009 and IDEAWILD to C.G., and by the projects P05-002 ICM and PFB 023 (Institute of Ecology and Biodiversity, Universidad de Chile), and INACH 02-02, 13-05 and ECOS C06B02 to E.P. Thank is also extended to international programs CAML, EBA-SCAR and PROSUL-Brazil for encouraging and supporting the Antarctic research in evolution. This is CAML contribution \#41.

\section{References}

Aljanabi, S.M., Martinez, I., 1997. Universal and rapid salt-extraction of high quality genomic DNA for PCR-based techniques. Nucleic Acids Research 25, 4692-4693.

Arnaud, P.M., López, C.M., Olaso, I., Ramil, F., Ramos-Esplá, A.A., Ramos, A., 1998. Semi-quantitative study of macrobenthic fauna in the region of the South Shetland Islands and the Antarctic Peninsula. Polar Biology 19, 160-166.

Arntz, W.E., Ríos, C., 1999. Magellan-Antarctic: ecosystems that drifted apart. Scientia Marina 63 (S1), 1-518.

Bargelloni, L., Zane, L., Derome, N., Lecointre, G., Patarnello, T., 2000. Molecular zoogeography of Antarctic euphausiids and notothenioids: from species phylogenies to intraspecific patterns of genetic variation. Antarctic Science 12, 259-268.

Bandelt, H.-J., Forster, P., Röhl, A., 1999. Median-joining networks for inferring intraspecific phylogenies. Molecular Biology and Evolution 16, 37-48.

Beaumont, A.R., Wei, J.H.C., 1991. Morphological and genetic variation in the Antarctic limpet Nacella concinna (Strebel, 1908). Journal of Molluscan Studies 57, 443-450.

Bird, C.E., Holland, B.S., Bowen, B.W., Toonen, R.J., 2007. Contrasting phylogeography in three endemic Hawaiian limpets (Cellana spp.) with similar life histories. Molecular Ecology 16, 3173-3186.

Bowden, D.A., 2005. Seasonality of recruitment in Antarctic sessile marine benthos. Marine Ecology Progress Series 297, 101-118.

Brandt, A., 2005. Evolution of Antarctic biodiversity in the context of the past: the importance of the Southern Ocean deep sea. Antarctic Science 17, 509-521.

Brandt, A., De Broyer, C., De Mesel, I., Ellingsen, E., Gooday, A.J., Hilbig, B., Linse, K., Tyler, P.A., 2007. The biodiversity of the deep Southern Ocean benthos. Phylosophical Transactions of the Royal Society of London B: Biological Science 362, 39-66.

Brêthes, J.-C., Ferreyra, G., de la Vega, S., 1994. Distribution, growth and reproduction of the limpet Nacella (Patinigera) concinna (Strebel, 1908) in relation to potential food availability, in Esperanza Bay (Antarctic Peninsula). Polar Biology 14, 161-170.

Brey, T., Dahm, C., Gorny, M., Klage, M., Stiller, M., Arntz, W.E., 1996. Do Antarctic marine benthic invertebrates show an extended level of eurybathy? Antarctic Science 8 3-6.

Chown, S.L., Lee, J.E., Shaw, J.D., 2008. Conservation of Southern Ocean Islands: invertebrates as exemplars. Journal of Insect Conservation 12, 277-291.

Clarke, A., Crame, J., 1989. The origin of the Southern Ocean marine fauna. In: Crame, J.A. (Ed.), Origins and Evolution of the Antarctic Biota, 47. Geological Society Special Publication, pp. 253-268.

Clarke, A., Johnston, N.M., 2003. Antarctic marine benthic diversity. Oceanography and Marine Biology: An Annual Review 41, 47-114.

Clarke, A., Aronson, R.B., Crame, J.A., Gili, J.-M., Blake, D.B., 2004. Evolution and diversity of the benthic fauna of the Southern Ocean continental shelf. Antarctic Science 16, 559-568.

Clarke, A., Barnes, D.K.A., Hodgson, D.A., 2005. How isolated is Antarctica? Trends in Ecology \& Evolution $201-3$. 
Convey, P., Gibson, J.A.E., Hillenbrand, C.-D., Hodgson, D.A., Pugh, P.J.A., Smellie, J.L., Stevens, M.I., 2008. Antarctic terrestrial life-challenging the history of the frozen continent. Biological Review 83, 103-117.

Côrte-Real, H.B.S.M., Hawkins, S.J., Thorpe, J.P., 1992. Genetic confirmation that intertidal and subtidal morphs of Patella ulyssiponensis aspera Roding (Mollusca: Gastropoda: Patellidae) are conspecific. Arquipélago 10, 55-66.

Crame, J.A., 1999. An evolutionary perspective on marine faunal connection between southernmost South America and Antarctica. Scientia Marina 63, $1-14$

D’Anatro, A.D., Lessa, E.P., 2006. Geometric morphometric analysis of geographic variation in the Río Negro tuco-tuco, Ctenomys rionegrensis. Mammalian Biology 71, 288-298.

Davenport, J., 1988. Tenacity of the Antarctic limpet Nacella concinna. Journal of Molluscan Studies 54, 355-356.

de Aranzamendi, M.C., Sahade, R., Tatián, M., Chiappero, B., 2008. Genetic differentiation between morphotypes in the Antarctic limpet Nacella concinna as revealed by inter-simple sequence repeat markers. Marine Biology 154, 875-885.

de Aranzamendi, M.C., Gardenal, C., Martin, J.P., Bastidas, R., 2009. Limpets of the genus Nacella (Patellogatropoda) from the Southwestern Atlantic: species identification based on molecular data. Journal of Molluscan Studies 75, $241-251$.

Díaz, A.D., 2008. Origen y evolución de la fauna marina bentónica antártica: diversidad genética y divergencia molecular entre especies congenéricas de Echinoidea de Antártica y Sudamérica. Tesis de Magíster. Universidad de Chile, Santiago, Chile. 65 pp (unpublished).

Díaz, A.D., Féral, J.-P., David, B., Saucède, T., Poulin, E., 2011. Evolutionary pathways among shallow and deep sea echinoids of the genus Sterechinus in the Southern Ocean. Deep-Sea Research II 58 (1-2), 205-211.

Dupanloup, I., Schneider, S., Excoffier, L., 2002. A simulated annealing approach to define the genetic structure of populations. Molecular Ecology 11, 2571-2581.

Excoffier, L., Laval, G., Schneider, S., 2005. Arlequin ver. 3.0: an integrated software package for population genetics data analysis. Evolution Bioinformatics Online $1,47-50$.

Filatov, D.A., 2002. PROSEQ: a software for preparation and evolutionary analysis of DNA sequence data sets. Molecular Ecology Notes 2, 621-624.

Goldstien, S.J., Schiel, D.R., Gemmel, N.J., 2006. Comparative phylogeography of coastal limpet across a marine disjunction in New Zealand. Molecular Ecology $15,3259-3268$

González-Wevar, C.A., Nakano, T., Cañete, J.I., Poulin, E., 2010. Molecular phylogeny and historical biogeography of Nacella (Patellogastropoda: Nacellidae) in the Southern Ocean. Molecular Phylogenetics and Evolution $56,115-124$.

Gray, J.S., 2001. Antarctic marine benthic biodiversity in a world-wide latitudinal context. Polar Biology 24, 633-641.

Gutt, J., Sirenko, B., Smirnov, I.S., Arntz, W.E., 2004. How many macrozoobenthicspecies might inhabit the Antarctic shelf? Antarctic Science 16 11-16.

Hammer, Ø., Harper, D.A.T., Ryan, P.D., 2001. PAST: paleontological statistics software package for education and data analysis. Paleontologia Electronica 1, $1-9$

Hedgpeth, J.W., 1969. Preliminary observations of life between tidemarks at Palmer Station, 64 $45^{\prime}$ 'S. Antarctic Journal of the United States 4, 106-107.

Ho, S.Y.W., Phillips, M.J., Cooper, A., Drummond, A.J., 2005. Time dependency of molecular rate estimated and systematic overestimation of recent divergence times. Molecular Biology and Evolution 22, 1561-1568.

Ho, S.Y.W., Shapiro, B., Phyllips, M.J., Cooper, A., Drummond, A.J., 2007. Evidence for time dependency of molecular rate estimates. Systematic Biology 56, 517-522.

Hoffman, J.I., Peck, L.S., Hillyard, G., Zieritz, A., Clark, M.S., 2010. No evidence for genetic differentiation between Antarctic limpet Nacella concinna morphotypes. Marine Biology 157 10.1007/s00227-009-1360-5.

Holsinger, K.E., Weir, B.S., 2009. Genetics in geographically structured populations: defining, estimating and interpreting $F_{\mathrm{ST}}$. Nature Reviews Genetics 10, 639-650.

Hunter, R.L., Halanych, K.M., 2008. Evaluating connectivity in the brooding brittle star Astrotoma agassizzi across the Drake Passage in the Southern Ocean. Journal of Heredity 99, 137-148.

Iwata, H., Ukai, Y., 2002. SHAPE: a computer program package for quantitative evaluation of biological shapes based on elliptic Fourier descriptors. Journal of Heredity 93, 384-385.

Jazdzweski, K., Jurasz, W., Presler, E., Sicinski, J., 1986. Abundance and biomass estimates of the benthic fauna in Admiralty Bay, King George Island, South Shetland Islands. Polar Biology 6, 5-16.

Krabbe, K., Leese, F., Mayer, C., Tollrian, R., Held, C., 2009. Cryptic mitochondrial lineages in the widespread pycnogonid Colossendeis megalonyx Hoek, 1881 from Antarctic and Subantarctic waters. Polar Biology 33, 281-292.

Kuhl, F.P., Giardina, C.R., 1982. Elliptic Fourier features of a closed contour. Comparative Graphic Image Process 18, 236-258.

Kuhner, M.K., Yamato, J., Felsenstein, J., 1998. Maximum likelihood estimation of population growth rates based on the coalescent. Genetics 149, 429-434.

Kumar, S., Tamura, K., Nei, M., 2004. MEGA3: integrated software for molecular evolutionary genetics analysis and sequence alignment. Briefings in Bioinformatics 5, 150-163.

Librado, P., Rozas, J., 2009. DnaSP v5: a software for comprehensive analysis of DNA polymorphism data. Bioinformatics 25, 1451-1452.

Lindberg, D.R., 1998. The Patellogastropoda. Malacological Reviews (4), 35-63.
Lindberg, D.R., 2008. The Patellogastropoda. In: Ponder, W.F., Lindberg, D.R. (Eds.) Phylogeny and Evolution of the Mollusca. University of California Press, pp. 271-296.

Mahon, A.R., Arango, C.P., Halanych, K.M., 2008. Genetic diversity of Nymphon (Arthropoda: Pignogonida: Nymphonidae) along the Antarctic Peninsula with focus on Nymphon australe Hodgson 1902. Marine Biology 155, 315-323.

Morriconi, E., Calvo, J., 1993. Influencia ambiental sobre el crecimiento alométrico de la valva en Nacella (Patinigera) deaurata (Gmelin, 1791) del Canal Beagle Argentina. Malacología 35, 135-140.

Nakano, T., Ozawa, T., 2005. Systematic revision of Patelloida pygmaea (Dunker 1860) (Gastropoda: Lottiidae), with a description of a new species. Journal of Molluscan Studies 71, 357-370.

Nakano, T., Ozawa, T., 2007. Worldwide phylogeography of limpets of the order Patellogastropoda: molecular, morphological and palaentological evidence. Journal of Molluscan Studies 73, 79-99.

Nakano, T., Spencer, H.G., 2007. Simultaneous polyphenism and cryptic species in an intertidal limpet from New Zealand. Molecular Phylogenetics and Evolution $45,470-479$.

Nei, M., 1987. Molecular Evolutionary Genetics. Columbia University Press New York.

Nolan, C.P., 1991. Size, shape and shell morphology in the Antarctic limpet Nacella concinna at Signy Island, South Orkney Islands. Journal of Molluscan Studies 57, 225-238.

Pagarete, A.J.P., Costa, M.J., Brito, C., 2005. Genetic conspecifity in two habitat morphs of the limpet Patella candei gomesii Drouët (Mollusca: Gastropoda: Patellidae) reinforces limpet morphological plasticity. JYI 12 (5).

Peck, L., Veal, R., 2001. Feeding, metabolism and growth in the Antarctic limpet, Nacella concinna (Strebel, 1908). Marine Biology 138, 553-560.

Peck, L., Clark, M.S., Clarke, A., Cockell, C.S., Convey, P., Detrich, I.I.I.H.W. Fraser, K.P.P., Johnston, I.A., Methe, B.A., Murray, A.E., Römisch, K., Rogers, A.D., 2005. Genomics: applications to Antarctic ecosystems. Polar Biology 28 251-265.

Picken, G.B., 1980. The distribution, growth, and reproduction of the Antarctic limpet Nacella (Patinigera) concinna (Strebel, 1908). Journal of Experimental Marine Biology and Ecology 42, 71-85.

Picken, G.B., Allan, D., 1983. Unique spawning behaviour by the Antarctic limpet Nacella (Patinigera) concinna (Strebel, 1908). Journal of Experimental Marine Biology and Ecology 71, 283-287.

Posada, D., Crandall, K.A., 2001. Intraspecific phylogenetics: trees grafting into networks. Trends in Ecology \& Evolution 16, 37-45.

Poulin, E., Palma, A., Féral, J.-P., 2002. Evolutionary versus ecological success in Antarctic benthic invertebrates. Trends in Ecology \& Evolution 17 218-222.

Powell, A.W.R., 1973. The Patellid Limpets of the World (Patellidae). In: Abbot, R.T (Ed.), Indo-Pacific-Mollusca, vol. 3. The Department of Mollusks, Greenville pp. 75-206.

Renaud, S., Michaux, J.R., 2003. Adaptative latitudinal trends in the mandible shape of Apodemus wood mice. Journal of Biogeography 30, 1617-1628.

Renaud, S., Michaux, J.R., 2007. Mandibles and molars of the wood mouse Apodemus sylvaticus (L): integrated latitudinal pattern and mosaic insular evolution. Journal of Biogeography 34, 339-355.

Roe, A.D., Sperling, F.A.H., 2007. Patterns of evolution of mitochondrial cytochrome oxidase I and II DNA and implications for DNA barcoding. Molecular Phylogenetics and Evolution 44, 325-345.

Rogers, A.R., 2007. Evolution and biodiversity of Antarctic organisms: a molecular perspective. Philosophical Transactions of the Royal Society of London B: Biological Science 362, 2191-2214.

Rogers, A.R., Harpending, H.C., 1992. Population growth makes waves in the distribution of pairwise genetic differences. Molecular Biology 9, 552-569.

Röhl, A., 2002. Network, netw3111.exe downloaded from the web site. 〈www. fluxus-engineering.com $>$.

Rohlf, F.J., Archie, J.W., 1984. A comparison of Fourier methods for the description of wing shape in mosquitoes (Ritera culicidae). Systematic Zoology 33 302-317.

Schneider, S., Excoffier, L., 1999. Estimation of past demographic parameters from the distribution of pairwise differences when the mutation rates vary among sites. Application to human mitochondrial DNA. Genetics 152 1079-1089.

Slatkin, M., Hudson, R.R., 1991. Pairwise comparisons of mitochondrial DNA sequences in stable and exponentially growing populations. Genetics 129 555-562.

Stanwell-Smith, D., Clarke, A., 1998. The timing of reproduction in the Antarctic limpet Nacella concinna (Strebel, 1908) (Patellidae) at Signy Island, in relation to environmental variables. Journal of Molluscan Studies 64 123-127.

Strugnell, J.M., Linse, K., 2005. Evolution of the Antarctic marine fauna: what can DNA and fossil tell us?. In: Cooper, A.K., Raymond, C.R., et al. (Eds.), Antarctica: A keystone in a Changing World-Online Proceedings of the 10th ISAES. USGS Open-File Report 2007-1047, Extended Abstracts 079, 4pp.

Thatje, S., Hillenbrand, C.-D., Larter, R., 2005. On the origin of Antarctic marine benthic community structure. Trends in Ecology \& Evolution 20, 534-540.

Thompson, J.D., Higgins, D.G., Gibson, T.J., 1992. Clustal W: improving the sensitivity of progressive multiple sequence alignment through sequence weighting, position specific gap penalties, and weight matrix choice. Nucleic Acids Research 22, 4673-4680. 
Thornhill, D.J., Mahon, A.R., Norenburg, J.L., Halanych, K.M., 2008. Open-ocean barriers to dispersal: a test case with the Antarctic Polar Front and the ribbon worm Parbolasia corrugatus (Nemertea: Lineidae). Molecular Ecology 17, 5104-5117.

Valdovinos, C., Rüth, M., 2005. Nacellidae limpets of the southern end of South America: taxonomy and distribution. Revista Chilena de Historia Natural 78 497-517.

Walker, A.J.M., 1972. Introduction to the ecology of the Antarctic limpet Patinigera polaris (Hombron and Jaquinot) at Signy Island, South Orkney Island. British Antarctic Survey Bulletin 28, 49-69.

Wilson, N.G., Hunter, R.L., Lockhart, S.J., Halanych, K.M., 2007. Multiple lineages and absence of panmixia in the "circumpolar" crinoid Promachocrinus kerguelenensis from the Atlantic sector of Antarctica. Marine Biology 152, 895-904.

Wilson, N.G., Schröld, M., Halanych, K.M., 2009. Ocean barriers and glaciation: evidence for explosive radiation of mitochondrial lineages in the Antarctic sea slug Doris kerguelenensis (Mollusca, Nudibranchia). Molecular Ecology 18, 965-984.

Zane, L., Marcato, S., Bargelloni, L., Bortolotto, E., Papetti, C., Simonato, M., Varotto, V., Patarnello, T., 2006. Demographic history and population structure of the Antarctic silverfish Pleurogramma antarticum. Molecular Ecology 15, 4499-4511.

Zachos, J., Pagani, M., Sloan, L., Thomas, E., Billups, K., 2001. Trends, rhythms, and aberrations on global climate $65 \mathrm{Ma}$ to present. Science 292, 686-693. 